\title{
PENANGANAN LUKA SEBAGAI UPAYA PENCEGAHAN KOMPLIKASI PADA SMA MA'ARIF PUNGGUR LAMPUNG TENGAH
}

\author{
Janu Purwono ${ }^{1}$, Tri Kesuma Dewi2 ${ }^{*}$, Sapti Ayubbana ${ }^{3} \&$ Senja Atika Sari ${ }^{4}$ \\ 1,2,3,4 Akademi Keperawatan Dharma Wacana \\ Jl. Kenanga No. 3, Metro Barat, Kota Metro, Lampung, Indonesia \\ *Korespondensi: trikusumadewi06@gmail.com
}

\begin{abstract}
Abstrak
Kecelakaan dan cidera adalah salah satu peristiwa yang tidak terpisahkan dari kehidupan. Kecelakaan dan cidera dapat terjadi dimana saja, kapan saja tanpa melihat usia. Kecelakaan juga banyak terjadi pada anak usia sekolah.Pertolongan pertama pada kecelakaan sangat penting dilakukan untuk mencegah komplikasi permanen, sehingga perlu dilakukan workshop penanganan luka pada anak usia sekolah khususnya disekolah menengah atas. Kegiatan pengabdian masyarakat ini, dilakukan di Sekolah Menengah Atas Ma`arif Punggur Lampung Tengah. Metode pengabdian masyarakat ini menggunakan metode seminar, simulasi dan role play. Hasil pengabdian masyarakat ini menunjukkan bahwa $75 \%$ peserta dapat menyerap informasi dengan baik serta dapat memperaktekkan kembali bagaimana cara penanganan luka yang diajarkan. Workshop penanganan luka seperti ini dapat terus dilakukan oleh pihak sekolah melalui kegiatan kesiswaan seperti PMI dan UKS.
\end{abstract}

Kata kunci: kecelakaan, cidera, perawatan luka

\section{ANALISIS SITUASI}

Kecelakaan dan cedera adalah bagian dari peristiwa sehari-hari. Kecelakan dan cedera dapat terjadi di rumah, di jalan dan disekolah. Kecelakaan dan cedara dapat menyebabkan masalah serius bila tidak ditangani dengan benar (Khatatbeh, 2016). Pertolongan pertama pada kecelakaan adalah langkah cepat, sementara dan sederhana dengan peralatan medis minimal yang dilakukan diluar rumah sakit untuk mencegah memperburuk kondisi hingga kedatangan penyedia pelayanan kesehatan (Alhejaili \& Alsubhi, 2016). Pertolongan pertama bukan sebagai pengobatan atau penanganan sempurna, namun pertolongan sementara yang dilakukan oleh petugas penolong pertama pada kecelakaan yang pertama melihat korban. Penolong dapat petugas kesehatan atau orang awan. 
Pertolongan pertama kecelakaan di sekolah dapat melalui kegiatan di Usaha Kesehatan Sekolah (UKS).Usaha Kesehatan Sekolah merupakan salah satu kesehatan pokok yang dilaksanakan oleh puskesmas dan merupakan usaha kesehatan masyarakat yang dijalankan oleh sekolah-sekolah (Effendi, 2009). Berdasarkan Undang-Undang No. 36 Tahun 2009 tentang Kesehatan Pasal 79 menyatakan bahwa "Kesehatan Sekolah diselenggarakan untuk meningkatkan kemampuan hidup sehat peserta didik dalam lingkungan hidup sehat sehingga peseta didik belajar tumbuh dan berkembang secara harmonis dan setinggi-tingginya menjadi Sumber Daya Manusia yang berkualitas."

Salah satu studi di Vancouver, British Colombia (Kanada) tingkat kecelakaan yang terjadi di lingkungan sekolah sebesar 1,8\% dari 100 anak. Penelitian tersebut melaporkan tingkat cidera kepala sebesar 1,8\% dari 100 anak, cidera yang meliputi perdarahan, terkilir, fraktur (patah tulang) dan gagar otak sebesar 0,09\% dari 100 anak. Sementara itu studi lain menyebutkan bahwa luka yang diderita oleh siswa SMA adalah $26,4 \%$ berada di jalan, 23,1\% terjadi di sekolah, 28,6\% aktivitas olahraga dan 22\% terjadi di rumah (Pratiwi, 2011).

Berdasarkan hasil penelitian yang dilakukan Sari (2011) pengaruh pelatihan balut bidai terhadap pengetahuan dan ketrampilan siswa yang dilakukan di SMAN 2 Sleman Yogyakarta menunujukkan 43,3\% kurang pengetahuan P3K. Selain itu penelitian ditingkat SMA di Jawa Tengah sebelumnya menunjukan bahwa pengetahuan bantuan hidup dasar siswa SMA YPH menunjukan 62,7\% tingkat pengetahuan kategori kurang, 4,5\% tingkat pengetahuan kategori buruk (Zulfa, 2014). Hal ini menunjukkan masih kurangnya pengetahuan dan tindakan P3K dikalangan siswa SMA.

\section{METODE PELAKSANAAN}

Metode yang digunakan dalam pelaksanaan pengabdian ini adalah seminar, simulasi dan role play, adapun susunan pelaksanan adalah sebagai berikut:

a. Persiapan. Pada tahap persiapan, penulis mengajukan proposal kegiatan kepada sekolah yang d tuju, setelah pihak sekolah menyetujui proposal tersebut maka langkah selanjutnya adalah menyusun jadwal kegiatan

b. Pelaksanan kegiatan. Langkah pertama adalah mempersiapkan alat dan bahan yang dibutuhkan, adapun alat dan bahan tersebut antara lain laptop, LCD, mitela, dan bidai. Langkah selanjutnya adalah menjelaskan konsep luka dan penanganannya melalui LCD. Kemudian, tim pengabdi mempraktekkan cara penanganan luka (role play). Terakhir para peserta pelatihan mencoba kembali apa yang sudah diajarkan oleh tim pengabdi. 
c. Evaluasi. Peserta dapat menjawab pertanyaan dan mempraktekkan kembali apa yang telah diajarkan.

\section{PELAKSANAAN DAN HASIL}

Kegiatan workshop penangan luka dilaksanakan sesuai rencana yaitu pada Rabu, 29 Januari 2020 bertempat di SMA Ma ’arif Punggur. Peserta terdiri dari 20 siswa SMA. Kegiatan dimulai dengan penjelasan tentang cara penanganan luka, mulai dari luka terbuka, luka bakar sampai patah tulang. Materi diberikan kurang lebih selama 45 menit, peserta menyimak penjelasan dengan seksama dilanjutkan dengan demonstrasi dan roleplay oleh para peserta. Seluruh perserta dapat menyerap informasi dengan baik yaitu $75 \%$ dapat mempraktekan kembali cara penanganan luka seperti cara membalut luka dan cara pembidaian.

Kegiatan ini menjadi suatu pengalaman dan bertambahnya ilmu bagi para peserta yang masih berusia remaja untuk mengetahui bagaimana cara penanganan awal pada luka sebelum dibawa ke pelayanan kesehatan. Antusias peserta dalam memperaktekan kembali apa yang di ajarkan serta diskusi yang berjalan cukup baik menjadi dasar bahwa mereka mengerti dan memahami cara penanganan awal pada luka.

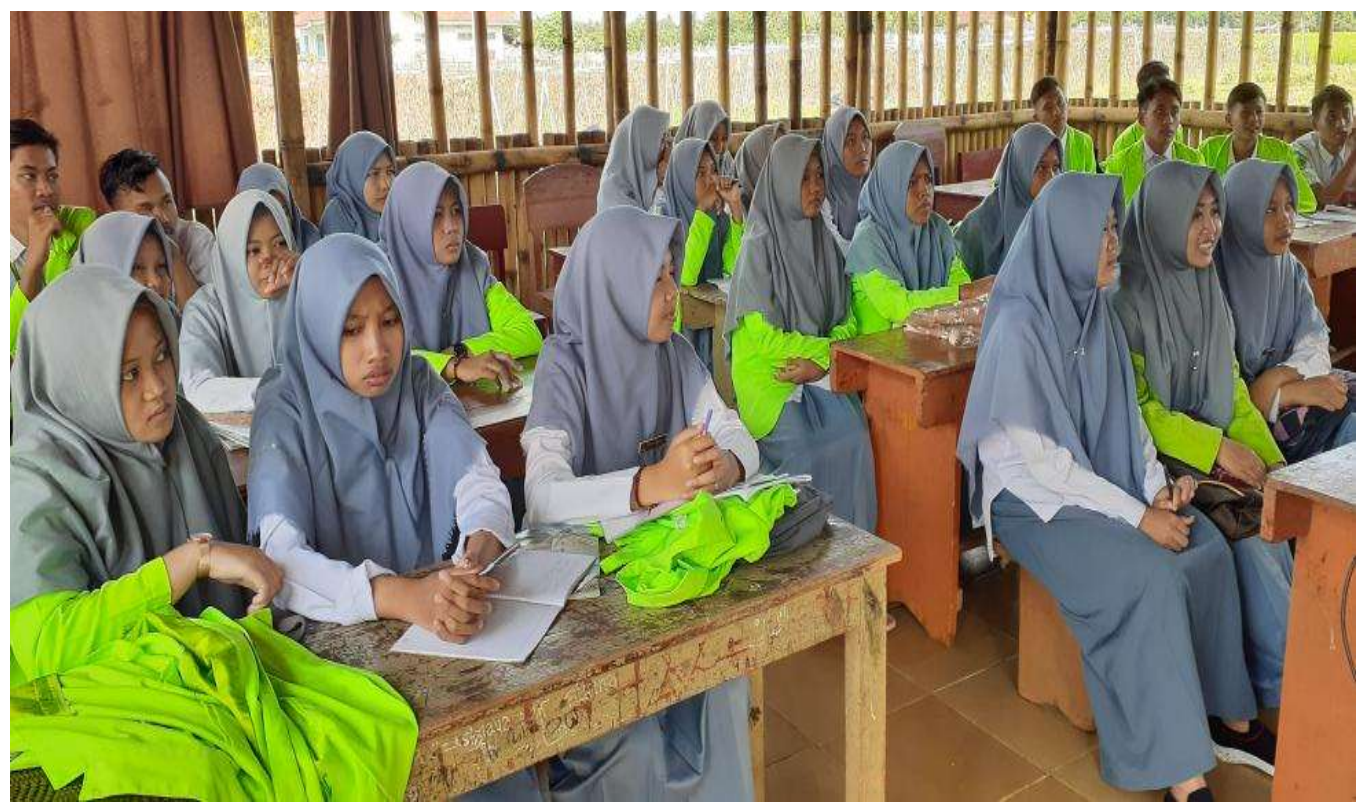

Gambar 1. Peserta menyimak materi yang disampaikan oleh tim pengabdian Sumber: Dokumentasi Tim Pengabdian, 2020 


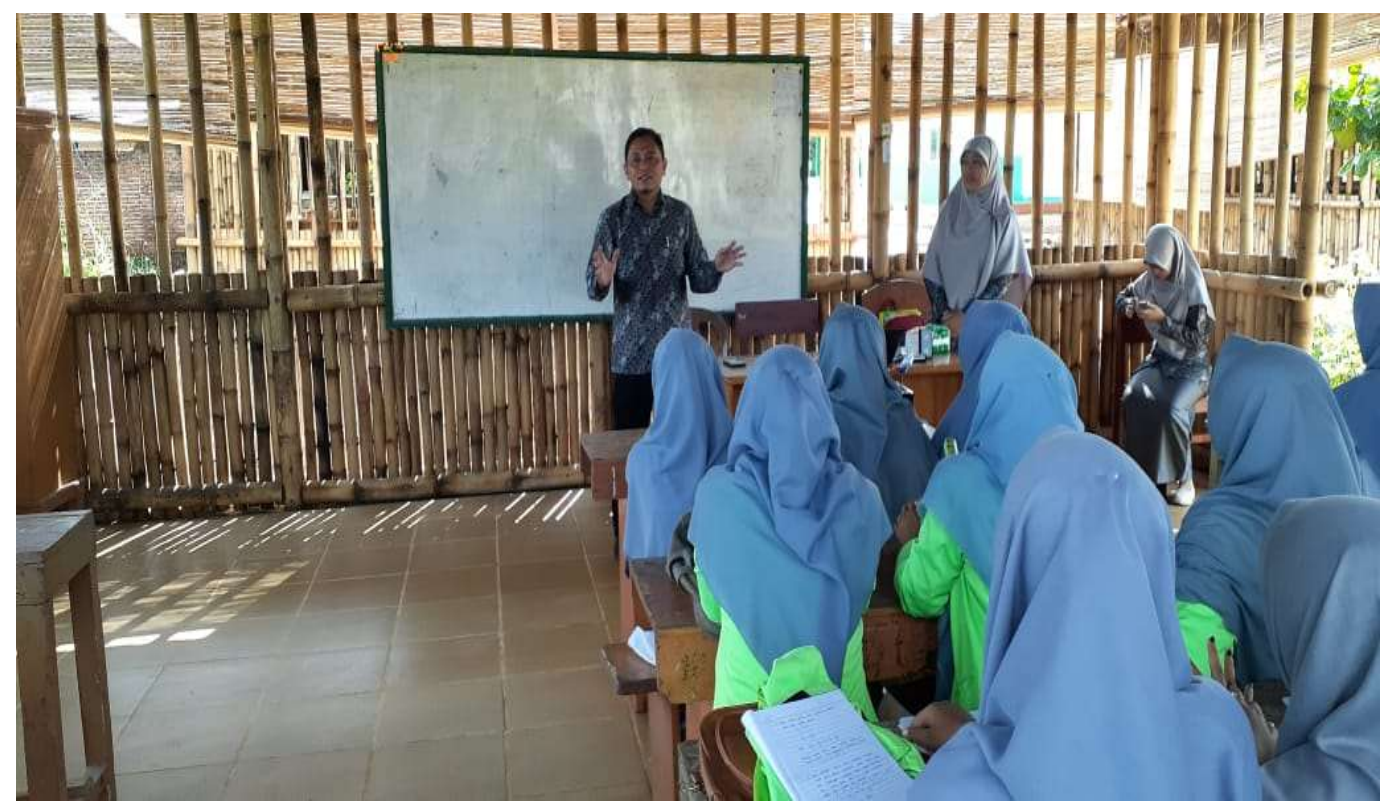

Gambar 2. Tim pengabdi menyampaikan materi Sumber: Dokumentasi Tim Pengabdian, 2020

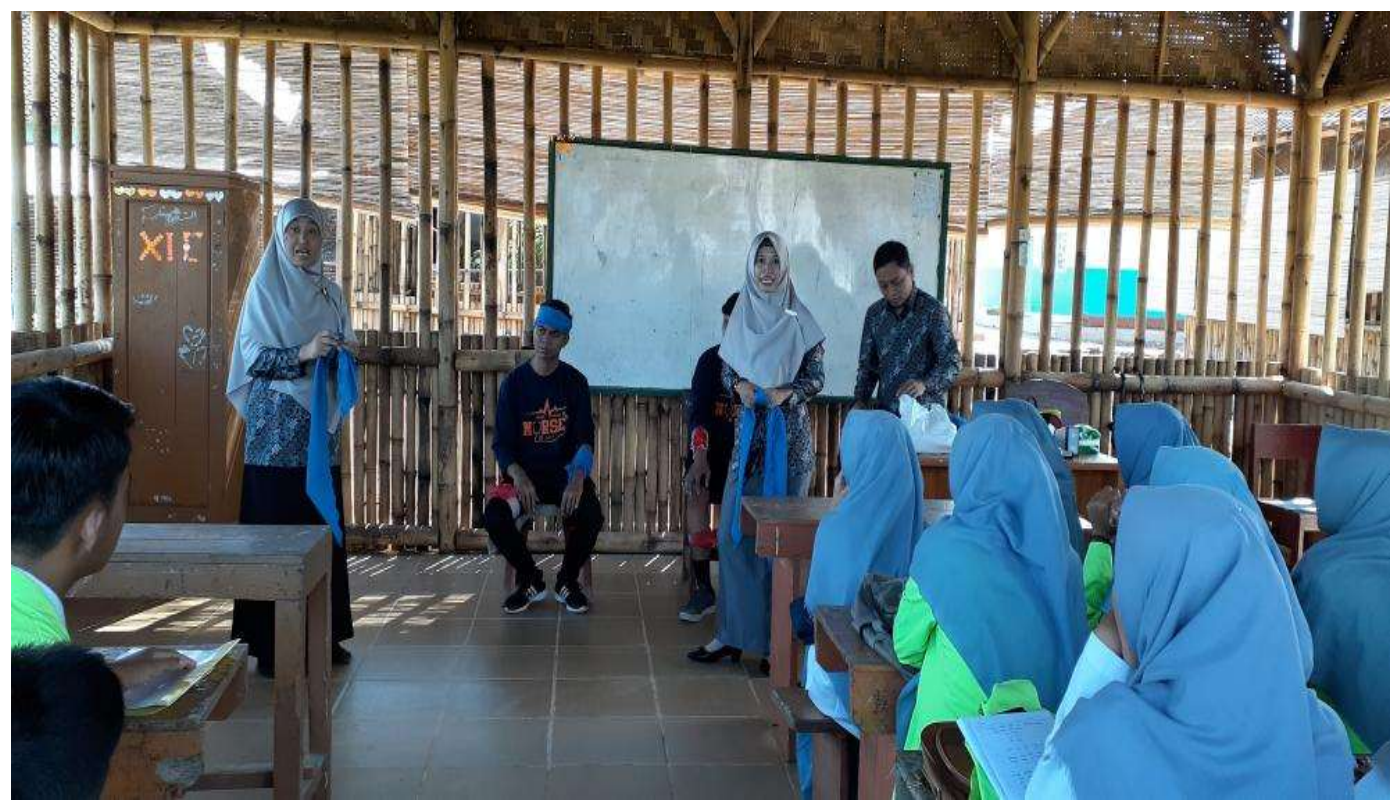

Gambar 3. Kegiatan roleplay

Sumber: Dokumentasi Tim Pengabdian, 2020

\section{PENUTUP}

Workshop penanganan luka berupa penjelasan materi, demonstrasi dan role play dilaksanakan pada tanggal 29 Januari 2020 berjalan dengan tertib dan lancar. $75 \%$ peserta dapat menyerap informasi dengan baik. Diskusi interaktif bagaimana cara penanganan luka berlangsung cukup baik. Perlu tindak lanjut oleh pihak sekolah 
untuk dapat memberikan kesempatan kegiatan workshop serupa dan lanjutan untuk meningkatkan pengetahuan siswa tentang penangan luka.

\section{UCAPAN TERIMA KASIH}

Pelaksanaan dan penyusunan artikel pengabdian masyarakat ini tidak terlepas dari dukungan berbagai pihak, oleh karena itu kami penulis menyampaikan terima kasih kepada para pihak yang telah mendukung terlaksananya pengabdian masyarakat yang menjadi dasar dalam penyusunan artikel ini. Terima kasih ini juga kami sampaikan kepada SMA Ma arif Punggur Lampung Tengah yang telah mengizinkan pelaksanaan kegiatan pengabdian masyarakat ini.

\section{DAFTAR PUSTAKA}

Alhejaili, A.S. \& Alsubhi, S.A. (2016). Knowledge and Attitude of First Aid Skills among Health Science Students at Taibah University. J Gen Practice, 4(257). doi:10.4172/2329-9126.1000257.

Effendi, F. (2009). Keperawatan Kesehatan Komunitas: Teori dan Praktek dalam Keperawatatan (volume: 1). Jakarta: Universitas Muhammadiyah.

Khatatbeh M. (2016). First Aid Knowledge Among University Students in Jordan. International journal of preventive medicine, 7(24). doi:10.4103/2008-7802.174772

Pratiwi. (2011). Kesiapan Anggota Palang Merah Remaja (PMR) dalam Melakukan Pertolongan Pertama Kegawatdaruratan di Sekolah. Ejournal Keperawatan (eKep),1. Yogyakarta: Universitas Gajah Mada Yogyakarta.

Sari, D.P.Y. (2015). Pengaruh Pelatihan Balut Bidai terhadap Pengetahuan dan Keterampilan Siswa di SMA Negeri 2 Sleman Yogyakarta. Ejournal Keperawatan (e-Kep), 1. Yogyakarta: STIKES Aiyiyah Yogyakarta.

Undang-Undang No. 36 Tahun 2009 tentang Kesehatan.

Zulfa. (2014). Gambaran Tingkat Pengetahuan Bantuan Hidup Dasar pada Siswa Siswi SMA Yayasan Persaudaraan Haji Bogor. Ejournal Keperawatan (e-Kep), 1. Jakarta. Universitas Muhammadiyah Jakarta. 
